\title{
СЕСТРИНСЬКА ДІЯЛЬНІСТЬ ПРИ ВИХОДЖУВАННІ НЕДОНОШЕНИХ ДІТЕЙ: СУЧАСНІ ПІДХОДИ
}

\author{
К. А. Шило \\ ДвНЗ «Тернопільський державний медичний університет \\ імені І. Я. Горбачевського МОз Украӥни»
}

У статті проаналізовано сучасні підходи до сестринської діяльності при виходжуванні недоношених дітей.

\section{NURSES’ ACTIVITIES IN THE NURSING OF PREMATURE INFANTS: CURRENT APPROACHES}

\author{
K. A. Shylo \\ I. Horbachevsky Ternopil State Medical University
}

The article analyzes modern approaches to nursing activities in the nursing premature.

Вступ. В останні роки проблема збереження життя і здоров'я недоношених дітей з дуже низькою масою тіла (ДНМТ) і екстремально низькою масою тіла (ЕНМТ) особливо зросла в нашій країні у зв'язку з удосконаленням технологій виходжування даної категорії дітей. Згідно з даними літератури, частота передчасних пологів у різних країнах становить від 5 до $12 \%$, в Україні - близько 7,7 \%. Частка недоношених дітей становить 6-12 \% від числа всіх новонароджених, з них на частку дітей з ДНМТ доводиться 1-1,8\%, а дітей з ЕНMТ - 0,4-0,5 \%. Здоров'я немовлят, які народилися з дуже низькою, особливо з екстремально низькою масою тіла, викликає занепокоєння у багатьох фахівців медичної та соціальної сфери, оскільки у цієї категорії дітей вища ймовірність інвалідизації, розвитку тяжких соматичних захворювань і патології ЦНС. За даними зарубіжних країн, серед дітей з масою тіла до 500 г виживають 12 \%, від 500 до 749 г - 50 \%, від 750 до 1000 г близько 80 \% дітей. Число здорових дітей, народжених із ДНМТ і ЕНМТ, не перевищує 10-25 \%, а відсоток тяжких неврологічних відхилень (інвалідність з дитинства - дитячий церебральний параліч, сліпота, глухота, розумова відсталість) становить від 12 до 32 \%. Частота несприятливих наслідків серед тих дітей, які вижили і народилися з масою до 1000 г, сягає

(c) К. А. Шило, 2017
40-50 \%, збільшуючись до 70-90 \% при народженні 3 масою 500-750 г. У числі причин дитячої інвалідності переважають хвороби нервової системи та органів чуття - понад $30 \%$, психічні розлади -12\%, хвороби органів дихання - $7 \%$.

Основна частина. Динамічне щомісячне спостереження допомагає батькам уникнути численних відвідувань медичних установ. При кожному відвідуванні проводять фізикальне обстеження, оцінку фізичного і психомоторного розвитку за коригувальним віком за шкалою КАТ/КЛАМС, оцінку лабораторних та інструментальних методів обстеження. 3 урахуванням віку і нутритивного статусу коригують харчування, призначають препарати для профілактики і лікування анемії, рахіту. 3 урахуванням виявлених відхилень вирішують питання про індивідуальний графік вакцинації дитини [5].

Дітям із бронхолегеневою дисплазією, вродженими вадами розвитку серця необхідно проводити специфічну профілактику респіраторно-синцитіальної вірусної інфекції палівізумабом - щомісяця під час холодного сезону, з жовтня до березня. У центрі катамнезу спостерігають недоношених дітей, які народилися на різних термінах гестації, але, як показує статистика, квота глибоко недоношених дітей становить приблизно 42 \% із загального числа спо- 
стережуваних дітей. Встановлено, що в групі недоношених дітей з дуже низькою і екстремально низькою масою тіла, імунізованих палівізумабом, загострення бронхолегеневого процесу протягом 1 року спостережень діагностовано в 3 рази рідше і мали більш сприятливий стан стосовно дітей групи порівняння. Побічні небажані реакції не виявлені.

Функціональні порушення шлунково-кишкового тракту $\epsilon$ дуже частою проблемою на першому році життя. Більшість дітей з ДНМТ і ЕНМТ скаржиться на зригування, запори, коліки [2]. Грижові випинання (пахвинно-мошонкові, пупкові) було виявлено у $37 \%$ дітей з ЕНМТ. Підбір медичною сестрою лікувального харчування, медикаментозної терапії, своєчасного введення прикорму допомагають поліпшити стан дітей до 6 місяців життя.

Для профілактики інвалідизації дітей корекція затримки психомоторного розвитку повинна починатися з перших місяців життя.

Реабілітація включає медикаментозні та немедикаментозні методи лікування (ЛФК, масаж, терапія Війта, фізіотерапія за показаннями). Масаж призначають при відсутності прихованої епіактивності, офтальмологічних ускладнень. На сучасному етапі виходжування дітей виникала потреба у створенні стандартів надання реабілітаційної допомоги та для підвищення ефективності раннього втручання.

Важливе значення в застереженні, профілактиці захворювань і догляді за новонародженими має санітарно-просвітницька робота з батьками. У відділенні за місцем проживання повинні обов'язково проводити лекції та бесіди з батьками за такими темами, як анатомо-фізіологічні особливості дитини, в тому числі недоношених дітей; перехідні стани адаптації новонароджених, неспецифічна профілактика різних захворювань і їх ускладнень в період новонародженості [11]. Матерів обов'язково навчають навичкам із догляду за новонародженими під постійним контролем медичної сестри відділення:

- консультування з вибору гігієнічних засобів для догляду за шкірою (крем, присипка), «приданого» для дитини;

\section{СПИСОК ЛІТЕРАТУРИ}

1. Бубнов В. Г. Основи медичних знань : навчальний посібник для вищої школи / В. Г. Бубнов. - М. : АСТ: Астрель, 2015. - 256 с.
- навчання матерів виконання необхідних маніпуляцій: термометрії, профілактики попрілості, профілактичного масажу тіла; сповивання;

- введення лікарських препаратів в очі, ніс та вуха;

- неспецифічні заходи щодо профілактики ОРЗ;

- профілактика анемії, рахіту і розладів харчування.

Одним із головних факторів, що сприяють правильному фізичному та нервово-психічному розвитку дитини, $є$ адекватне за віком і станом здоров'я харчування. Тому питання дієти недоношених дітей в роботі з матерями стоять на першому місці та викликають у них найбільший інтерес:

- значення грудного вигодовування для дитини та матері і техніка годування груддю;

- раціональна дієта жінки, яка годує груддю, і профілактика гіпогалактії;

- техніка штучного вигодовування і консультування з підбору молочних сумішей [13]. Повноцінне природне вигодовування, враховуючи ситуацію з недоношеними, доступне не всім, тому використовують спеціалізовані суміші для ентерального харчування недоношених.

Підбір суміші та визначення строків початку ентерального харчування здійснює лікар з урахуванням таких параметрів:

- термін гестації на момент народження;

- загальний соматичний і неврологічний статус;

- стабільність гемодинаміки;

- відсутність розладів із боку шлунково-кишкового тракту (здуття живота, шлункова кровотеча, закид жовчі в шлунковий вміст та ін.) [9].

Висновки. Проблема недоношених дітей у всьому світі актуальна щодня, адже серед них великий відсоток розумово відсталих, фізично неповноцінних, з недостатнім інтелектом і епілептичними нападами і т. д.

Таким дітям дуже складно перебувати серед своїх однолітків і в суспільстві. Розвиток технологій виходжування дітей з ЕНМТ є невід'ємним і для дітей інших вагових категорій - дозволяє в повному обсязі поліпшити результати виходжування більш зрілих і перспективних новонароджених.

3 огляду отриманих літературних джерел нам вдалося з'ясувати, що для кращих результатів у розвитку та виходжуванні недоношеної дитини є сімейноорієнтований підхід.

2. Медсестринський догляд за пацієнтом / І. Я. Губенко, О. Т. Шевченко, Л. П. Бразолій, В. Г. Апшай. - К. : Здоров'я, 2010. - 248 c. 
3. Медсестринський процес: основи сестринської справи та клінічного медсестринства / І. Я. Губенко, О. Т. Шевченко, Л. П. Бразолій, В. Г. Апшай. - К. : Здоров'я, 2011. - 208 c.

4. Двойникова С. І. Організація сестринського процесу / С. І. Двойникова, Л. А. Карасьова // Медична допомога. 2016. - № 3. - С. 17-19.

5. Дмитрієва 3. В. Теоретичні основи сестринської справи / З. В. Дмитрієва, А. І. Теплова. - М. : СпецЛит, 2010. - 319 c.

6. Зорянська В. Г. Сестринська справа / В. Г. Зорянська, Н. В. Барикіна. - Ростов-на-Дону : ФЕНІКС, 2010. - 448 с.

7. Касевич Н. М. Практикум із сестринської справи : навч. посіб. - К. : Здоров'я, 2015. - 464 с.

8. Ковальчук О. Л. Медсестринство в хірургії / О. Л. Ковальчук, Р. О. Сабадишин, С. В. Маркович. - Тернопіль : Укрмедкнига, 2012. - 480 с.

9. Медсестринство в педіатрії / за ред. В. С. Тарасюка. К. : Здоров'я, 2011. - 254 с.

10. Мухіна С. А. Практичний посібник до предмету «Основи сестринської справи» / С. А. Мухіна, І. І. Тарновська. - Джерело, 2009. - 545 с.
11. Мухіна С. А. Теоретичні основи сестринської справи / С. А. Мухіна, І. І. Тарновська. - М. : ГЕОТАР-Медіа, 2010. - 147 с.

12. Мухіна С. А. Теоретичні основи сестринської справи / С. А. Мухіна, І. І. Тарновська. - Частина I-II. - М. : Дрофа, 2016. - 518 c.

13. Основи догляду в домашніх умовах : навч. посіб. для патронажних медичних сестер / за заг. ред. І. Т. Усіченка, А. В. Царенка, С. А. Місяка. - Тернопіль : Укрмедкнига, 2000. - 372 c.

14. Пропедевтика внутрішніх хвороб з доглядом за терапевтичними хворими / за заг. ред. А. В. Єпішина. Тернопіль : Укрмедкнига, 2015. - 288 с.

15. Lung protective strategies for premature infants / G. Moriette, L. Mayry, P. le Hudoux [et al.] // Arch. Pediatr. 2005. - Vol. 12, № 5. - P. 573-578.

16. Mode of delivery and risk of respiratory diseases in newborns / E. Levine, V. Ghai, J. Barton [et al.] // Obstet. Gynecol. - 2001. - Vol. 97, № 3. - P. 439.

17. Pulmonary microvascular fracture in patient with acute respiratory distress syndrome /J.R. Hotchkiss, D.A. Simonson, D. J. Marek [et al.] // Crit. Care Med. - 2002. - Vol. 30, № 10. - P. 2368-2370. 